\title{
Chapter 15 \\ Policy Options for Life Cycle Assessment Deployment in Legislation
}

\author{
Annekatrin Lehmann, Matthias Finkbeiner, Clare Broadbent, \\ and Russ T. Balzer
}

\begin{abstract}
Life cycle thinking is on the political agenda and widely used in practice. Moreover, numerous industries have actively been developing life cycle assessment (LCA) approaches for many years. As the authors think that it is in substance "right" to base environmental legislation on LCA, they started to explore and to develop policy options for integrating LCA into legislation. Commissioned by WorldAutoSteel, the authors focused on $\mathrm{CO}_{2}$ legislation in the automotive industry, but the options developed based on this example can be used for other industries and other environmental impacts as well. It was found that theoretically a broad range of policy options exists, and that practically some of them are already implemented in real world legislation and that there is no clear scientific overall preference for one single option. It was also shown that solutions for most technical requirements are already available, but that a consensus on proper setting of these requirements is missing.
\end{abstract}

Keywords Automotive sector $\bullet \mathrm{CO}_{2} \bullet$ Legislation $\bullet$ Life cycle assessment $\bullet$ Life cycle management $\bullet$ Life cycle thinking $\bullet$ Policy initiatives

\section{Introduction}

Life cycle thinking (LCT) and life cycle assessment (LCA) (ISO 14044 2006) (Baitz et al. 2012; Finkbeiner 2012) gain increasing importance in policy (Reimann et al. 2010; Inaba et al. 2003) and the authors think that to base environmental legislation on LCA is in substance "right". In fact, LCT is already considered in

\footnotetext{
A. Lehmann $(\bowtie) \cdot$ M. Finkbeiner

Technische Universität Berlin, Strasse des 17. Juni 135, 10623 Berlin, Germany

e-mail: annekatrin.lehmann@tu-berlin.de

C. Broadbent

World Steel Association, Brussels, Belgium

R.T. Balzer

WorldAutoSteel, Springboro, OH, USA 
some current legislations and investigated in ongoing policy initiatives, e.g. the Product Environmental Footprint method (PEF) (European Union 2013), which is currently widely discussed amongst various stakeholders (Finkbeiner 2014; Galatola and Pant 2014; Lehmann et al. 2015). Besides this, LCA has been widely applied in practice for many years, and several industries, companies and associations are actively developing LCA approaches (Finkbeiner et al. 2000). Examples are the World Steel Association and WorldAutoSteel, its automotive group, which published their position to plea for $\mathrm{LC}$ based regulation, e.g. in automotive $\mathrm{CO}_{2}$ legislation and proposes to consider LCT in post 2020 legislation (World Steel Association 2013).

Against this background, in 2013 WorldAutoSteel commissioned Technische Universität Berlin (TUB) to explore and develop policy options for integrating LCA into (automotive) legislation. The research project is still ongoing.

Automotive $\mathrm{CO}_{2}$ legislation is a relevant example for illustrating the necessity for considering a LC perspective. The reason is that it is shown that the current focus on tailpipe or exhaust emissions (the use phase) is not sustainable anymore because $\mathrm{CO}_{2}$ reductions in the use phase can come along with increasing $\mathrm{CO}_{2}$ emissions in other LC phases like the production phase (Daimler 2014; Krinke 2009; Kendall and Price 2012; PE International 2013), which are typically referred to as the embodied energy or environmental footprint.

The first idea in the research project was to "simply" move from tailpipe based $\mathrm{CO}_{2}$ limits to $\mathrm{LC}$ based $\mathrm{CO}_{2}$ limits. But the second thought was to explore alternative policy options as well. The underlying methodology and the results are presented in Sects. 2 and 3 respectively. A discussion of the key findings and an outlook is provided in Sect. 4.

Though the policy options are developed and described for the example of $\mathrm{CO}_{2}$ legislation in the automotive sector, they generally can be transferred to other sectors and other environmental impacts as well.

\section{Methodology}

The methodology of the research process to explore and describe different policy options is presented below. It comprises the identification of various policy options including prioritization and the identification and description of characteristics of the prioritized policy options, including e.g. technical requirements as well as potential strengths, opportunities, and threats.

\subsection{Identification of Policy Options}

To identify the policy options, the authors chose both a theoretical and practical approach. In the theoretical approach, they used four different structural elements, which were combined to develop policy options. In the practical approach, they 
Table 15.1 Structural elements to define policy options, their features and description

\begin{tabular}{l|l|l}
\hline $\begin{array}{l}\text { Structural } \\
\text { elements }\end{array}$ & $\begin{array}{l}\text { Features of policy } \\
\text { option }\end{array}$ & Description of the policy option features \\
\hline $\begin{array}{l}\text { Type of } \\
\text { enforcement }\end{array}$ & Mandatory & $\begin{array}{l}\text { Policy is legally binding; defined requirements (e.g. } \\
\text { limit/target values) have to be fulfilled }\end{array}$ \\
\cline { 2 - 3 } & Voluntary & $\begin{array}{l}\text { Policy is not legally binding, but intends to have } \\
\text { indirect effects }\end{array}$ \\
\hline Levers & Performance & $\begin{array}{l}\text { Policy defines product requirements; if they are not } \\
\text { met, product needs to be re-designed }\end{array}$ \\
\cline { 2 - 3 } & Process & $\begin{array}{l}\text { Policy defines requirements on company level for } \\
\text { process improvement }\end{array}$ \\
\hline Use of LCA & Direct (full LCA) & $\begin{array}{l}\text { Policy directly defines LC based limit/target values } \\
\text { and/or requires communication of full LCA results }\end{array}$ \\
\cline { 2 - 3 } Market role & Indirect (LCT) & $\begin{array}{l}\text { "Backoffice" use of LCA or LCA data during policy } \\
\text { development such as target value setting processes }\end{array}$ \\
\cline { 2 - 3 } & Market access & $\begin{array}{l}\text { Policy provides minimum requirements (threshold } \\
\text { values) for products to be able to enter the market }\end{array}$ \\
\cline { 2 - 3 } & Market incentive & $\begin{array}{l}\text { Policy provides framework (e.g. criteria) for } \\
\text { promoting environmentally preferred products }\end{array}$ \\
\hline
\end{tabular}

analyzed existing legislations, which are related to $\mathrm{CO}_{2}$ and/or have implemented LCT, i.e., include an LC perspective. A first focus was put on Europe (EU).

The structural elements are summarized in Table 15.1 and describe individual features of possible policy options. The features reflect different types of enforcement (mandatory or voluntary), different levers (on a process- or a product level), different stringencies on the use of LCA (consideration of full LCA or LCT) and different market roles (access or incentive). The policy options defined based on the structural elements as well as theoretical and practical examples (where available) are presented in Sect. 3.

Regarding the market role of policy options: "market access" is used to exclude products (and services or processes) that have a low performance, e.g. environmental performance - from the market (typically ca. 10-20\% of products). An example of how to implement this market role is the Conformité Européenne (CE)-mark (EC 2015). "Market incentive" usually aims at promoting the 10-20\% "best in class" products (and services or processes). It can for example promote environmentally friendly products by using the Eco label type I (ISO 14024 1999) labelling system in the market. Therefore the majority of products (ca. 70-80 \%) are set in between these two market roles. ${ }^{1}$ General effects of "market access" and "market incentive" policy options on the share of environmentally preferred products on the market are shown in Fig. 15.1.

After having identified various policy options, they were prioritized based on three criteria, namely rigor of implementation (referring to the type of enforcement

\footnotetext{
${ }^{1}$ These two roles can be implemented by several policy tools e.g. type approval, limit values, permits, labels, taxes, subsidies, and procurement rules (e.g., Green Public Procurement (GPP).
} 


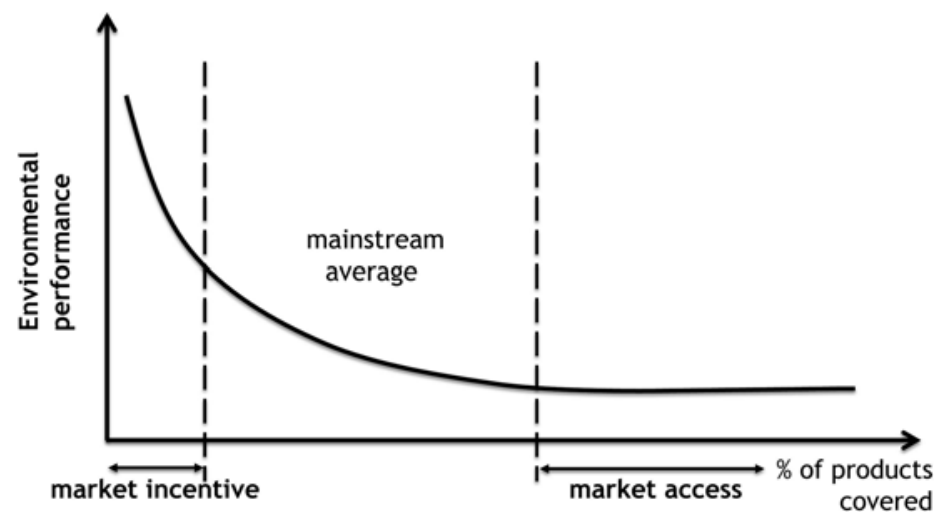

Fig. 15.1 Effects of "market access" and "market incentive" policy options on the share of environmentally preferred products on the market

and to the levers), rigor of LCA (referring to the extent of LCA use) and stakeholder acceptance (referring to an assumed acceptance or willingness of stakeholders for LC implementation). The prioritized policy options were subject of further detailed analyses, described in the following section.

\subsection{Identification and Description of Characteristics of the Policy Options}

Characteristics here refer to technical requirements for policy implementation. These requirements also determine (though not solely) further characteristics of the policy options like applicability (easiness) or acceptance and thus are relevant to identify for example potential strengths or threats of the particular options.

For this work, the authors specified six technical requirements, namely methodology, models, data, tools, quality assurance and communication and described them for the prioritized policy options. Based on this, they further analyzed the options using a SWOT ${ }^{2}$ analysis to reveal their potential strengths, weaknesses, opportunities and threats. This analysis was complemented by the RACER ${ }^{3}$ analysis, which originates from the European Commission's Impact Assessment Guidelines (EC 2009) to assess the value of scientific tools for use in policy making based on the criteria relevance, acceptance, credibility, easiness and robustness. For both the SWOT and the RACER analysis different stakeholder perspectives were considered obtained

\footnotetext{
${ }^{2}$ SWOT: strengths, weaknesses, opportunities, threats.

${ }^{3}$ RACER: relevance, acceptance, credibility, easiness, robustness.
} 
from stakeholder meetings with policy makers, original equipment manufacturers (OEMs), material industries and academia in Europe and beyond (in the USA, Japan and China).

\section{Results and Discussion}

The following two sections present selected results of the ongoing research process. The results focus on a detailed theoretical description of the identified policy options for LCA deployment in legislation including existing examples from practice. In addition - but on a higher level - key findings from the analysis of the characteristics of the policy options are provided.

\subsection{Developed Policy Options}

Based on the theoretical approach, by combining different structural elements describing policy features, eleven policy options for LCA deployment were developed. The options range from voluntary to mandatory policies, describe legislations with and without direct effects on the product design, legislations which are either fully LCA based or which consider LCA or LCA data during policy development (without requiring full LCAs) and legislations addressing two different market roles i.e., "market incentive" and "market access".

An overview of the 11 policy options identified is presented in Fig. 15.2. For voluntary policy options, the feature "market access" is not foreseen because of the nature of the policy options, they are not legally binding but intend to have indirect effects on the market.

The following sections provide further details on the policy options, including examples of how these options could theoretically look like. Moreover, examples from practice (focusing on Europe) are provided, allocated to the theoretical options and showing that some of the options are in fact already implemented in real world legislation. The sections are differentiated between mandatory-performance based options, mandatory-process based options and voluntary policy options.

\subsubsection{Mandatory-Performance Based Policy Options}

These options cover mandatory policies, thus "hard" legislations, which are based on product performance. Consequently, they have a direct effect on the product design and may require a product re-design. The mandatory-performance-direct policy option (Table 15.2) is the most stringent solution for using LCA in policy, while the mandatory-performance-indirect option (Table 15.3) is less stringent as it does not require full LCAs. The latter can be seen as an intermediate step for full 


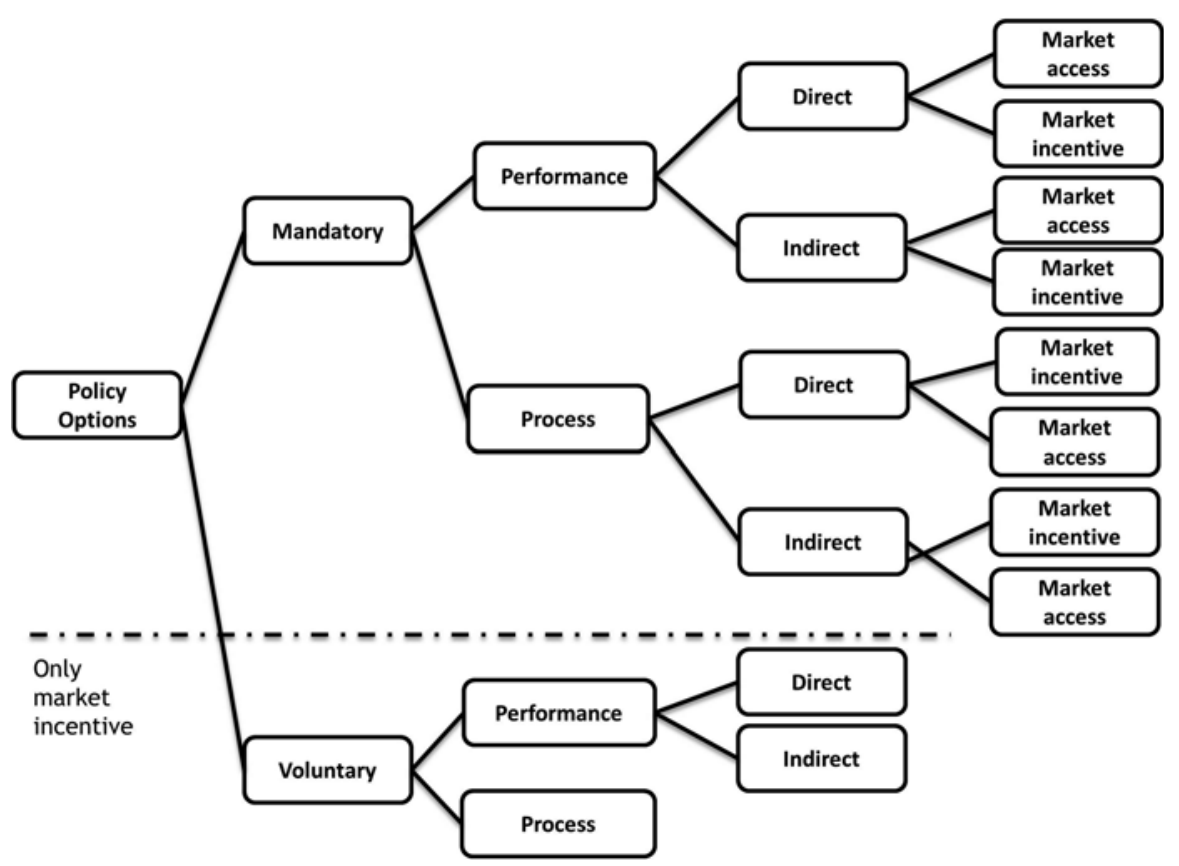

Fig. 15.2 Policy options for LCA deployment in legislation

Table 15.2 Mandatory-performance-direct policy options - theoretical and practical examples differentiated according to the market role

\begin{tabular}{|c|c|c|}
\hline \multicolumn{3}{|c|}{ Mandatory-performance-direct policy options } \\
\hline $\begin{array}{l}\text { Market } \\
\text { role }\end{array}$ & $\begin{array}{l}\text { Theoretical example ( } \mathrm{LC} \mathrm{CO}_{2} \text { legislation } \\
\text { of cars) }\end{array}$ & Examples from practice $(\mathrm{EU})$ \\
\hline Access & $\begin{array}{l}\text { Company has to show a proof that } \mathrm{LC} \mathrm{CO}_{2} \\
\text { emissions do not exceed defined limit } \\
\text { values; e.g. an EU fleet limit of } 100 \mathrm{~g} \mathrm{LC} \\
\mathrm{CO}_{2} / \mathrm{km} \text { or LC limit values per vehicle class }\end{array}$ & $\begin{array}{l}\text { Renewable Energy Directive (RED): } \\
\text { LC based limit values are provided } \\
\text { for renewable energies; e.g. if the } \\
\text { company shows that their biofuels } \\
\text { meet these targets, they can enter } \\
\text { the market as biofuels }\end{array}$ \\
\hline \multirow[t]{2}{*}{ Incentive } & $\begin{array}{l}\text { (a) Company has to provide } \mathrm{LC} \mathrm{CO}_{2} \text { values; } \\
\text { the performance is used for criteria in GPP }\end{array}$ & \multirow[t]{2}{*}{ No policy in the EU } \\
\hline & $\begin{array}{l}\text { (b) Company has to show } \mathrm{LC} \mathrm{CO}_{2} \\
\text { emissions, e.g. by using an "LC } \mathrm{CO}_{2} \text {-label"; } \\
\text { possible market advantage if consumers } \\
\text { consider environmental performance for } \\
\text { purchase decisions }\end{array}$ & \\
\hline
\end{tabular}


Table 15.3 Mandatory-performance-indirect policy options - theoretical and practical examples differentiated according to the market role

\begin{tabular}{|c|c|c|}
\hline \multicolumn{3}{|c|}{ Mandatory-performance-indirect policy options } \\
\hline $\begin{array}{l}\text { Market } \\
\text { role }\end{array}$ & $\begin{array}{l}\text { Theoretical example }\left(\mathrm{LC} \mathrm{CO}_{2}\right. \\
\text { legislation of cars) }\end{array}$ & Examples from practice (EU) \\
\hline Access & $\begin{array}{l}\text { Company has to show a proof } \\
\text { that } \mathrm{CO}_{2} \text { emissions in relevant } \\
\text { phases, e.g. in the use phase of } \\
\text { a car do not exceed defined } \\
\text { values, e.g. } \mathrm{Xg} \mathrm{CO}_{2} / \mathrm{km} \text { in use } \\
\text { phase or } \mathrm{Yg} \mathrm{CO} / \mathrm{kg} \text { in the } \\
\text { production phase of car }\end{array}$ & $\begin{array}{l}\text { EU Ecodesign Directive: } \\
\text { Uses LCA studies in the preparatory study to } \\
\text { identify implementing measures which are not } \\
\text { full LC based }\end{array}$ \\
\hline \multirow[t]{2}{*}{ Incentive } & \multirow{2}{*}{$\begin{array}{l}\text { Company has to show/publish } \\
\mathrm{CO}_{2} \text { emissions, which occur in } \\
\text { a relevant phase, e.g. the use } \\
\text { phase of a car (e.g. by using a } \\
\text { non- } \mathrm{LC} \mathrm{CO}_{2} \text { label) }\end{array}$} & $\begin{array}{l}\text { (a) } \mathrm{CO}_{2} \text { label for vehicle: } \\
\text { Information on tailpipe } \mathrm{CO}_{2} \text { emissions per km } \\
\text { has to be available at the point of sale in } \mathrm{EU}\end{array}$ \\
\hline & & $\begin{array}{l}\text { (b) Clean Vehicles Directives: } \\
\text { Requires that energy/environmental impacts } \\
\text { linked to the operation of vehicles over their } \\
\text { whole lifetime are considered in all purchases } \\
\text { of road transport vehicles, as covered by the } \\
\text { public procurement (PP) directives and the } \\
\text { public service regulation }\end{array}$ \\
\hline
\end{tabular}

LCA based legislation. It also reflects existing policies, which are especially relevant for the automotive industry (e.g. $\mathrm{CO}_{2}$-label for tailpipe emissions).

\subsubsection{Mandatory-Process Based Policy Options}

These options capture mandatory policies, thus "hard" legislations, which are not directly related to product performance but refer to technical aspects of process based policies, e.g. requirements on a company level for continuous improvement. Thus, they are less stringent than the performance based options. The mandatoryprocess-direct policy option (Table 15.4) can be seen as intermediate steps to use LCA as basis for performance based legislation. The mandatory-process-indirect policy options (Table 15.5) as the weakest form of mandatory legislation can be considered as an introductory step towards full LC based (direct) and/or performance based legislation.

\subsubsection{Voluntary Policy Options}

These options cover voluntary policies, thus "soft" legislations. The voluntaryperformance-direct and -indirect options are based on product performance, and can have a direct effect on the product and may require a product re-design. 
Table 15.4 Mandatory-process-direct policy options - theoretical and practical examples differentiated according to the market role

\begin{tabular}{|c|c|c|}
\hline \multicolumn{3}{|c|}{ Mandatory-process-direct policy options } \\
\hline Market role & Theoretical example ( $\mathrm{LC} \mathrm{CO}_{2}$ legislation of cars) & $\begin{array}{l}\text { Examples } \\
\text { from practice } \\
\text { (EU) }\end{array}$ \\
\hline Access & $\begin{array}{l}\text { Company uses LCA to determine } \mathrm{LC} \mathrm{CO}_{2} \text {-emissions, e.g. an } \\
\text { environmental product declaration (EPD) must be available, } \\
\text { but the product performance documented is not decisive for } \\
\text { type approval }\end{array}$ & $\begin{array}{l}\text { No policy } \\
\text { in the EU }\end{array}$ \\
\hline Incentive & $\begin{array}{l}\mathrm{LC} \mathrm{CO} \text { values must be available for GPP, e.g. for having } \\
\text { an EPD a bonus in PP can be received, but the product } \\
\text { performance documented is not relevant }\end{array}$ & $\begin{array}{l}\text { No policy } \\
\text { in the EU }\end{array}$ \\
\hline
\end{tabular}

Table 15.5 Mandatory-process-indirect policy options - theoretical and practical examples differentiated according to the market role

\begin{tabular}{l|l|l}
\hline Mandatory-process-indirect policy options \\
\hline Market role & $\begin{array}{l}\text { Theoretical example (LC CO} 2 \text { legislation } \\
\text { of cars) }\end{array}$ & Examples from practice (EU) \\
\hline Access & $\begin{array}{l}\text { (a) Company has to show a proof that } \mathrm{CO}_{2} \\
\text { emission values in relevant phases (e.g. use } \\
\text { phase) are determined (e.g. average values/ } \\
\text { fleet) }\end{array}$ & $\begin{array}{l}\text { End-of-Life Vehicles Directive } \\
\text { (ELV): } \\
\text { Requires to provide recycling/ } \\
\text { dismantling information as part } \\
\text { of the type approval }\end{array}$ \\
\cline { 1 - 2 } $\begin{array}{l}\text { (b) Company has to demonstrate a "certified" } \\
\text { management system/strategy to decrease } \mathrm{CO}_{2} \\
\text { for cars which is based on LCT, but does not } \\
\text { require full LCA implementation }\end{array}$ & \\
\hline Incentive & $\begin{array}{l}\text { (a) Company gets more points if it has an } \\
\text { Environmental Management Auditing system } \\
\text { (EMAS) for GPP; the information must be } \\
\text { available }\end{array}$ & No policy in the EU \\
\hline & $\begin{array}{l}\text { (b) Company has to show that } \mathrm{CO}_{2} \text { emissions, } \\
\text { in relevant phases (e.g. use phase) are } \\
\text { determined and documented, e.g. using a } \\
\text { non-quantitative label like "we have used } \\
\text { LCA"; providing this could bring bonuses }\end{array}$ & \\
\hline
\end{tabular}

The voluntary-performance-direct option is the strongest voluntary policy option and can be seen as an introductory step to reduce resistance against mandatory legislations. The same applies to the voluntary-performance-indirect option, which additionally can be considered as basis for full LC based legislations. The voluntary-process based option is the weakest policy option and represents a very first step towards performance based and mandatory legislations. Further details on the three voluntary policy options as well as theoretical and practical examples are provided in Table 15.6. 
Table 15.6 Voluntary-performance-direct and -indirect and voluntary-process based options theoretical and practical examples (market role: only incentive)

\begin{tabular}{l|l|l}
\hline \multirow{2}{*}{ Policy options } & $\begin{array}{l}\text { Theoretical example (LC CO} \\
\text { legislation of cars) }\end{array}$ & Examples from practice (EU) \\
\hline $\begin{array}{l}\text { Voluntary-performance- } \\
\text { direct }\end{array}$ & $\begin{array}{l}\text { (a) Recommendation to show LC } \\
\mathrm{CO}_{2} \text { emissions, e.g. using a label } \\
\text { (LC } \mathrm{CO}_{2} \text { label) }\end{array}$ & $\begin{array}{l}\text { GPP: } \\
\text { Allows including full LC } \\
\text { performance criteria in GPP }\end{array}$ \\
\cline { 2 - 3 } & $\begin{array}{l}\text { (b) Recommendation to use } \\
\text { performance criteria documented } \\
\text { in EPDs for GPP }\end{array}$ & \\
\hline $\begin{array}{l}\text { Voluntary-performance- } \\
\text { indirect }\end{array}$ & $\begin{array}{l}\text { Recommendation to show } \mathrm{CO}_{2} \\
\text { emissions which occur in relevant } \\
\text { phases, e.g. the use phase of a } \\
\text { car, e.g. by using a label }\end{array}$ & $\begin{array}{l}\text { EU flower: } \\
\text { LCA is used to develop criteria }\end{array}$ \\
\hline Voluntary-process & $\begin{array}{l}\text { Recommendation to present } \\
\mathrm{CO} \text {-emissions as part of e.g. } \\
\text { EMAS/inclusion of information } \\
\text { on } \mathrm{CO}_{2} \text { emissions in } \\
\text { environmental program }\end{array}$ & $\begin{array}{l}\text { EMAS: } \\
\text { Recommends using LCA } \\
\text { in the process of continuously } \\
\text { improving the company's } \\
\text { environmental performance }\end{array}$ \\
\hline
\end{tabular}

As described in Sect. 2.1, in a second step the identified policy options were prioritized. The following four policy options were selected:

- Mandatory-performance-direct

- Mandatory-performance-indirect

- Mandatory-process-direct

- Voluntary-performance-direct

These policy options cover the whole range of policy option features defined in Table 15.1: mandatory and voluntary options, options with and without effects on the product design as well as options which use full LCA or LCA as "backoffice" for legislation. For these four options, further detailed analyses were conducted. The high level results are summarized in the next section.

\subsection{Characteristics of the Prioritized Policy Options}

The different policy options require different solutions for implementation, which depend on their particular characteristics. The characteristics of the four prioritized policy options were described taking into account the technical requirements, methodology, models, tools, data, quality assurance and communication.

It was found that the differences between the policy options are partly not very significant and that some technical requirements are the same for both voluntary and mandatory policies. For example, all direct policy options, which consider the full LC, have some technical requirements, which are similar for all of them, e.g. the need of LCA data and LCA tool(s) and the need to specify the product system 
model and LCIA model as well as characterization factors. On the other hand, indirect policy options - with its "backoffice" use of LCA - generally may have less strict technical requirements than direct options. Moreover, it was shown, that sometimes, voluntary policy options have stricter requirements than mandatory options, for example with regard to communication as they require a specific communication format to reach the consumer.

The technical requirements of the particular policy options also determine their applicability (efforts), comparability, robustness, relevance or stakeholder acceptance, and thus are relevant for their feasibility and probability of implementation. The SWOT and RACER analysis from different stakeholder perspectives revealed that generally highest relevance regarding $\mathrm{CO}_{2}$ reduction, but also highest efforts for implementation seem to be related to the mandatory-performance-direct option. Moreover, it was shown that robustness and credibility can principally be guaranteed by all policy options and that acceptance strongly depends on the perspective of the stakeholders. Generally, it can be assumed that if the policy options are implemented properly, the acceptance is high, but if there is a risk of poor implementation the acceptance would be low.

\section{Conclusions and Outlook}

Within the first phase of the research process, promising policy options were identified and their characteristics were described. It was found that theoretically a broad range of options for implementing LCA into policy exists and that practically (with focus on the EU) some of them are already implemented in real world legislation. Moreover, it was shown that there is no clear analytical, scientific overall preference for one single policy option: for example, possible trade-offs were revealed (e.g. showing that some technical requirements may be lower for a particular policy option, others may be higher) and naturally no "black-and-white" results from the SWOT and RACER analysis were obtained. Also, it was found that technical implementation strongly depends on the implementation level and that solutions for most technical requirements are already available, ${ }^{4}$ but that a consensus on the proper setting of these requirements is missing.

The selected portfolio of policy options and the knowledge on their potential benefits and shortcomings allow the development of a concept of how an LCA methodology can be used in future automotive emission regulations. Preliminary implementation scenarios were already described (but are not addressed in this

\footnotetext{
${ }^{4}$ For example, different available LCA methodologies (e.g., ISO 14044, Product Environmental Footprint (PEF)), databases for background data (Sonnemann et al. 2011), e.g., European Reference Life Cycle Data System (ELCD) from the European Commission (EC n.d.), ecoinvent, PE International) or data collection formats (Finkbeiner et al. 2003), models (e.g., UCSB model by WorldAutoSteel or the model from the European Aluminum Association (EAA)) or communication formats (e.g., EPDs, labels).
} 
chapter), outlining how current regulations could potentially be amended to include a $\mathrm{LC}$ perspective and/or how new co-existing $\mathrm{LC}$ based $\mathrm{CO}_{2}$ regulations could look.

The research process continues in 2015 and includes a broader stakeholder dialogue in the EU and beyond to communicate and refine the policy options as well as to specify possible implementation pathways for policy options aiming at LCA deployment in legislation. Though the focus in this work is/was laid on $\mathrm{CO}_{2}$ legislation in the automotive industry, the policy options developed can be used for other industries and other environmental impacts as well.

Open Access This chapter is distributed under the terms of the Creative Commons Attribution Noncommercial License, which permits any noncommercial use, distribution, and reproduction in any medium, provided the original author(s) and source are credited.

\section{References}

Baitz M et al (2012) LCA's theory and practice: like ebony and ivory living in perfect harmony? Int J Life Cycle Assess 18(1):5-13, http://link.springer.com/10.1007/s11367-012-0476-x. Accessed 25 Oct 2013

Daimler AG (2014) Mercedes-Benz cars: 2014. Environmental brochure. smart fortwo electric drive. https://www.daimler.com/Projects/c2c/channel/documents/2243139_Environmental_ brochure_smart_fortwo_electric_drive.pdf. Accessed 24 Nov 2014

EC (2009) Impact assessment guidelines. SEC (2009) 92. http://ec.europa.eu/smart-regulation/ impact/commission_guidelines/docs/iag_2009_en.pdf

EC (2015) CE marking. http://ec.europa.eu/enterprise/policies/single-market-goods/cemarking/. Accessed 2 Mar 2015

European Platform on LCA (EPLCA). http://eplca.jrc.ec.europa.eu/. Accessed 28 Feb 2015

European Union (2013) Commission Recommendation of 9 April 2013 on the use of common methods to measure and communicate the life cycle environmental performance of products and organisations. Off J Eur Union L124

Finkbeiner M (2012) From the 40s to the 70s - the future of LCA in the ISO 14000. Int J Life Cycle Assess 18(1):1-4

Finkbeiner M (2014) Product environmental footprint - breakthrough or breakdown for policy implementation of life cycle assessment? Int J Life Cycle Assess 19(2):266-271

Finkbeiner $\mathrm{M}$ et al (2000) Life cycle engineering as a tool for design for environment. In: Total life cycle conference of the Society of Automotive Engineers in Detroit, USA, vol 26, p 189, 28 Apr 2000

Finkbeiner M et al (2003) Data collection format for life cycle assessment of the German association of the automotive industry. Int J Life Cycle Assess 8(6):379-381

Galatola M, Pant R (2014) Reply to the editorial "Product environmental footprint - breakthrough or breakdown for policy implementation of life cycle assessment?" written by Prof. Finkbeiner (Int J Life Cycle Assess 19(2):266-271). Int J Life Cycle Assess, 19(6):1356-1360

Inaba A et al (2003) Practical tools and thoughtful principles for sustainability. Int J Life Cycle Assess 8(1):1-5

ISO 14024 (1999) Environmental labels and declarations - type I environmental labelling principles and procedures

ISO 14044 (2006) International standard - environmental management - life cycle assessment requirements and guidelines

Kendall A, Price L (2012) Emissions, incorporating time-corrected life cycle greenhouse gas emissions in vehicle regulations. Environ Sci Technol 46:2557-2563 
Krinke S (2009) Environmentally friendly vehicles and environmental strategy of the brand Volkswagen, 19 Nov 2009

Lehmann A, Bach V, Finkbeiner M (2015) Product environmental footprint in policy and market decisions - applicability and impact assessment. Integr Environ Assess Manag, doi:10.1002/ ieam

PE International (2013) Life cycle assessment of low carbon cars 2020-2030, London. http:// www.lowcvp.org.uk/resource-library/reports-and-studies.htm

Reimann K, Finkbeiner M, Horvath A, Matsuno Y (2010) Evaluation of environmental life cycle approaches for policy and decision making support in micro and macro level applications. JRC-IES

Sonnemann G et al (2011) Process on "global guidance for LCA databases". Int J Life Cycle Assess 16:95-97

World Steel Association (2013) Steel industry calls on member states for life cycle approach to EU vehicle emissions from 2020. http://www.worldsteel.org/media-centre/press-releases/2013/2020Vehicles-Emissions-Life-Cycle.html. Accessed 28 Feb 2015 